\title{
ISOLATION OF CARBOXYPEPTIDASE Y BY AFFINITY CHROMATOGRAPHY
}

\author{
by \\ J. T. JOHANSEN \\ K. BREDDAM \\ M. OTTESEN \\ Department of Chemistry - Carlsberg Laboratory \\ Gamle Carlsberg Vej 10 - DK-2500 Copenhagen, Valby
}

Keywords: Carboxypeptidase Y, Yeast, Affinity chromatography.

Carboxypeptidase $Y$ from bakers' yeast has been purified in high yields by affinity chromatography. The affinity gel was prepared by coupling the specific inhibitor p-aminobenzylsuccinic acid via an azo linkage to Sepharoseglycyl-tyrosine. This affinity gel was able to bind carboxypeptidase $Y$ specifically and quantitatively from a crude yeast autolysate.

The isolated enzyme appeared homogeneous by gel electrophoresis and ultracentrifugation, while isoelectric focusing revealed the presence of two components with isoelectric points of pH 3.56 and 3.66, respectively. Small differences in amino acid composition and enzymatic properties between the enzyme from danish yeast and the corresponding enzyme isolated from Fleichmann yeast suggested the existence of more than one form of this enzyme.

\section{INTRODUCTION}

Ten years ago DoI, HATA and HAYASHI isolated a new proteolytic enzyme from bakers' yeast (I1) which later was shown to be a member of the class of enzymes termed wacid carboxypeptidases" by ZUBER and MATILE (34) or mserine carboxypeptidases by HAYASHI et al. (16). These carboxypeptidases are characterized by activity in the acid $\mathrm{pH}$ range, lack of metal atoms and inhibition by diisopropyl phosphorofluoridate. Since enzymes within this class originating from different sources display chemical differences, HAYASHI et al. have suggested that the enzyme from yeast be named carboxypeptidase $Y$ (17). The broad specificity of this enzyme, including the ability to liberate proline residues, has made it a useful tool in sequence studies $(17,23)$. Although the original procedure used for the isolation of carboxypeptidase $Y$ (11) has been improved by 
both HAYASHI et al. (17) and KUHN et al. (21), it is still tedious to isolate this enzyme in large quantities by traditional ion exchange procedures. Benzylsuccinate is a specific and potent inhibitor of bovine carboxypeptidase $A$ catalysed reactions, and SOKOLOWSKY and Peterson have suggested (personal communication) that this agent might also be an effective inhibitor of carboxypeptidase $Y$ and hence an ideal ligand for preparation of an insoluble support for affinity chromatography. The present paper reports the preparation of a benzylsuccinate Sepharose derivative and its use for purification of carboxypeptidase $Y$ from a crude yeast autolysate.

\section{EXPERIMENTAL}

\subsection{Materials}

Compressed bakers' yeast was obtained from De danske Spritfabrikker. Para-nitrobenzylsuccinic acid was kindly donated by Dr. M. SoKolowsky and Dr. L. PETERson, Biophysics Research Laboratory, Harvard Medical School, Boston, U. S. A. N-Carbobenzoxy-Lphenylalanyl-L-alanine*), N-acetyl-L-tyrosine ethyl ester, para-hydroxymercuribenzoate, phenylboronic acid, ribonuclease $A$, sodium dodecyl sulphate, glucosamine-hydrochloride, and $2(\mathrm{~N}$-morpholino) ethanesulfonic acid were obtained from Sigma Chemical Company, St. Louis, U. S. A. N-carbobenzoxy-L-phenylalanyl-L-leucine and L-1-tosylamido-2-phenylethylchloromethyl ketone from Cyclo Chemicals, Los Angeles, U. S. A. Succinic acid, $\beta$-mercaptoethanol, urea, cyanogen bromide and all analytical reagents for buffers were purchased from Merck, Darmstadt, West Germany. Diisopropyl phosphorofluoridate was a laboratory preparation. Sepharose-4B and Sephadex DEAE-A-50 were products of Pharmacia, Uppsala, Sweden. The B-chain of oxidized insulin had been prepared in this laboratory according to the method of BANG-
JENSEN et al. (4). Bovine serum albumin was obtained from the British Drug House, Poole, England. Carbonic anhydrase was prepared by an affinity chromatographic procedure by $\mathrm{J}$. T. JOHANSEN (in press). Ovalbumin was prepared according to the method of SøRENSEN (30).

\subsection{Preparation of the affinity gel.}

Preliminary experiments demonstrated that $D, L-b e n z y l s u c c i n i c ~ a c i d$, a very strong inhibitor of carboxypeptidase A (7), also was a strong inhibitor of carboxypeptidase Y. For this reason, the preparation of an affinity gel was attempted by diazotisation of amino benzylsuccinic acid and coupling to Sepharose through a Gly-Tyr "spacer-arm".

In a typical preparation, $100 \mathrm{ml}$ of packed Sepharose 4B was washed and suspended in 100 $\mathrm{ml}$ water. It was activated by addition of $17 \mathrm{~g}$ of cyanogen bromide to the well-stirred suspension (9). The $\mathrm{pH}$ of the reaction mixture was maintained at about 10.5 by continous addition of $6 \mathrm{M}-\mathrm{NaOH}$. Ice was added in amounts sufficient to maintain the temperature at about $20^{\circ} \mathrm{C}$. After $10-15 \mathrm{~min}$ of reaction, the rate slowed down as indicated by a decreased base consumption. The activated Sepharose suspension was rapidly filtered, washed with one liter of ice-cold water, and half a liter of cold $0.1 \mathrm{M}$ $\mathrm{NaHCO}_{3}, \mathrm{pH}$ 9.5. The activated Sepharose was resuspended at $0^{\circ} \mathrm{C}$ in $100 \mathrm{ml}$ of the same buffer containing $1 \mathrm{~g}$ of Gly-Tyr. The total time for the washing and the addition of ligand was restricted to about $5 \mathrm{~min}$. The Sepharose-GlyTyr suspension was stirred for 3 days at $4^{\circ} \mathrm{C}$ in order to deactivate any unoccupied binding sites, and then washed repeatedly with large volumes of water. This procedure resulted in a derivative containing about $4 \mu$ moles Gly-Tyr per $\mathrm{ml}$ of packed Sepharose, as determined from amino acid analysis.

Para-aminobenzylsuccinic acid was prepared by catalytic hydrogenation of $200 \mathrm{mg} \mathrm{p}$ nitrobenzylsuccinic acid suspended in $8 \mathrm{ml}$

*) Abbreviations used: Cbz-Phe-Ala, N-Carbobenzoxy-L-phenylalanyl-L-alanine; Cbz-Phe-Leu, N-Carbobenzoxy-L-phenylalanyl-L-leucine; MES, 2(N-morpholino) ethanesulfonic acid; ATEE, N-acetyl-L-tyrosine ethyl ester; PHMB, para-hydroxymercuribenzoate; Gly-Tyr, glycyl-L-tyrosine; HPLA, Hippuryl-L- $\beta$-phennyllactate; DFP, Diisopropyl phosphorofluoridate; TPCK, L-1-tosylamido-2-phenylethyl-chloromethyl ketone. 
water containing $160 \mathrm{mg}$ of $\mathrm{Pd}$ on charcoal and adjusted to $\mathrm{pH} 7$. After three hours of reaction, the catalyst was removed by filtration and the resulting solution of $\mathrm{p}$-aminobenzylsuccinic acid was diazotized immediately without further purification. $37 \mathrm{ml}$ of ice-cold $1 \mathrm{M}-\mathrm{HCl}$ was added to the p-aminobenzyl-succinic acid solution followed by $390 \mathrm{mg} \mathrm{NaNO}$ in $20 \mathrm{ml}$ water. After $8-10 \mathrm{~min}$ of reaction at $0^{\circ} \mathrm{C}$ the diazotized benzylsuccinate was added to a suspension of $100 \mathrm{ml}$ of packed Sepharose-GlyTyr in $200 \mathrm{ml}$ of $0.1 \mathrm{M}-\mathrm{Na}_{2} \mathrm{CO}_{3}$. The $\mathrm{pH}$ was adjusted to 9.5 . The Sepharose derivative slowly turned orange, and after 3 hours of reaction at $0^{\circ} \mathrm{C}$, the gel was washed with $0.1 \mathrm{M}-\mathrm{NaHCO}_{3}$, $\mathrm{pH}$ 9.5, and several times with water. The gel could be stored over long periods as a suspension in water at $4^{\circ} \mathrm{C}$.

\subsection{Amino acid analysis.}

The samples were hydrolysed in $6 \mathrm{M}$-hydrochloric acid at $110^{\circ} \mathrm{C}$ in vacuo for 24,48 and 72 hours (27). The evaporated hydrolysates were analyzed on a Durrum D-500 amino acid analyser. Tryptophan contents were determined by the method of Goodwin and MORTON (14). Half-cystine and methionine were determined as cysteic acid and methionine sulfone, respectively, after performic acid oxidations (18).

\subsection{Carbohydrate determinations}

An approximate estimation of the total carbohydrate content of carboxypeptidase $Y$ was obtained by means of the phenol-sulfuric acid procedure of DuBors (12) using a similarly treated galactose-mannose mixture $(1: 1 \mathrm{w} / \mathrm{w})$ as standard. Contents of hexosamine were determined by the ninhydrin reaction after hydrolysis in $6 \mathrm{M}$-hydrochloric acid at $100^{\circ} \mathrm{C}$ for 8,6 or 3 hours by chromatography on the short column (Aminex A-5 resin) of a Beckman Model 120 amino acid analyzer. The glucosamine was eluted with a sodium citrate buffer, pH 5.28. No peptides interfered with the determination, since the elution profile of the hexosamine peak was symmetrical and the baseline was low. Glucosamine hydrochloride was used as reference.

\subsection{Electrophoresis}

The purification of carboxypeptidase $\mathrm{Y}$ was followed by disc gel electrophoresis using a Canalco Model 1200 apparatus and 7.5\% polyacrylamide gels, buffered at pH 4.3 with glycine-acetate (6), or at $\mathrm{pH} 8.8$ with Tris (10). The latter was performed with a stacking gel, buffered at $\mathrm{pH} 6.7$.

The molecular weight of the enzyme was estimated by SDS gel elctrophoresis according to WEBER et al. (32), using $\beta$-mercaptoethanol as reducing agent. The following proteins were used as references: Bovine serum albumin, ovalbumin and carbonic anhydrase.

\subsection{LItracentrifuge analysis}

A Spinco Model E analytical ultracentrifuge equipped with both schlieren and interference optics was used for measurements of sedimentation velocity rates at $59,780 \mathrm{rev} / \mathrm{min}$ in a sodium phosphate buffer, $\mathrm{pH} 7.0 \mathrm{I}=0.1$. Sedimentation equilibrium measurements according to the procedure of YPHANTIS (33) were performed at $17,980 \mathrm{rev} . / \mathrm{min}$ and $20^{\circ} \mathrm{C}$ in a sodium phosphate buffer, $I=0.1, \mathrm{pH} 7.0$. Preliminary experiments showed this speed to be appropriate while $11,260 \mathrm{rev} . / \mathrm{min}$ was insufficient to give a protein free zone at the meniscus and at $24,430 \mathrm{rev} . / \mathrm{min}$ the protein concentration gradient was too steep to make the calculation of the molecular weight reliable. The partial specific volume of carboxypeptidase $\mathrm{Y}$ was determined from density measurements, by means of a Digital Densitometer Model DMA 02 from Anton Paar, Austria, which gave results reproduceable within $\pm 10^{-6} \mathrm{~g} / \mathrm{ml}(20)$.

\subsection{Isoelectric focusing}

Isoelectric focusing of $15 \mathrm{mg}$ carboxypeptidase $Y$ was performed in a LKB 8101 column (110 $\mathrm{ml}$ ) using an Ampholine gradient from $\mathrm{pH} 2.5$ to 4 . A sucrose gradient from zero to $20 \%$ was used to stabilize the pH-gradient and the column was thermostatted at $7^{\circ} \mathrm{C}$. After $68 \mathrm{~h}$ of electrophoresis, the content of the column was eluted in $0.75 \mathrm{ml}$ fractions. The $\mathrm{pH}$ and the absorbance of each fraction was measured with a Radiometer PHM-63 pH meter and a Cary $118 \mathrm{C}$ spectrophotometer, respectively. 


\subsection{Peptidase activity}

The exopeptidase activities were measured from the decrease in absorbance at $230 \mathrm{~nm}$ during hydrolysis of the substrates Cbz-Phe-Ala and Cbz-Phe-Leu. $10 \mu$ l of enzyme solution was added to $1 \mathrm{ml}$ of substrate containing $50 \mathrm{mM}$ MES. The substrate solution had previously been extracted with $0.01 \%$ dithizone in carbon tetrachloride to eliminate possible metal contaminations (31). A Cary $118 \mathrm{C}$ spectrophotometer thermostatted at $25^{\circ} \mathrm{C}$, was used for the absorbance measurements. Routine assays were performed with $2 \mathrm{mM} \mathrm{Cbz}$-Phe-Ala at $\mathrm{pH}$ 6.75 .

\subsection{Esterase activity}

Activities against ATEE and HPLA were determined by the pH-stat method (28) using a Radiometer titrator Model TTT la combined with an Ole Dich recorder. The substrate solution $(5 \mathrm{ml})$ contained $0.1 \mathrm{M}-\mathrm{KCl}$, and $1 \mathrm{mM}$ EDTA. When ATEE was used as substrate the solution contained in addition $2 \%$ dioxane. The $\mathrm{pH}$ was kept constant by addition of $0.05 \mathrm{M}$ $\mathrm{NaOH}$ and the reaction mixture was maintained at $25^{\circ} \mathrm{C}$ under a slow stream nitrogen. Routine assays of the enzymatic activity against $10 \mathrm{mM}$-ATEE were performed at $\mathrm{pH}$ 8.0.

\subsection{Inhibition studies}

The conditions of the routine assays of the enzymatic activities against Cbz-Phe-Ala and ATEE (see Sections 2.8 and 2.9) were used to study the inhibitory power of D,L-benzylsuccinic acid, $\beta$-phenylpropionic acid, sodium acetate, succinic acid, p-aminophenylarsonic acid, p-aminophenylphosphonic acid and benzeneboronic acid. The reaction with DFP was performed at $25^{\circ} \mathrm{C}$ with a reagent to enzyme ratio of 10:1 adding the DFP from a $0.1 \mathrm{M}$ stock solution in isopropanol. The enzymatic activity was assayed after $30 \mathrm{~min}$ of reaction. The effect of PHMB on the different activities of the carboxypeptidase was investigated using the following reaction conditions: The enzyme $(0.125 \mathrm{mg} / \mathrm{ml})$ was incubated with the reagent for $60 \mathrm{~min}$ in a phosphate buffer $\mathrm{pH} 7.0$ at room temperature to secure the completion of the reaction, and a concentration of reagent of $5.6 \times 10^{-7}$ to $3.5 \times 10^{-5} \mathrm{M}$ was used.

\subsection{Enzyme concentration}

The concentration of carboxypeptidase $\mathrm{Y}$ was measured spectrophotometrically using the factor $\mathrm{E}_{28 \mathrm{~nm}}^{\%}=14.8$, which was determined in a separate experiment by drying a lyophilized sample of purified carboxypeptidase $Y$ to constant weight at $110^{\circ} \mathrm{C}$.

\section{RESULTS}

\subsection{Isolation and purification of carboxypeptidase $Y$.}

The initial autolysis of the yeast cells and the activation of the extract were similar to the previously published procedures $(11,17,21$, 22). In a typical preparation, $500 \mathrm{~g}$ of compressed bakers' yeast was crushed and intimately mixed with $250 \mathrm{ml}$ of ether. After I hour the yeast was liquified, $750 \mathrm{ml}$ water was added, the $\mathrm{pH}$ was adjusted to 7.4 and the suspension was left at $25^{\circ} \mathrm{C}$ for 21 hours. The autolysate was centrifuged at $2900 \mathrm{rev} . / \mathrm{min}$ for $45 \mathrm{~min}$ to remove cell debris. No carboxypeptidase activity was detected at this stage, presumably because the carboxypeptidase existed in a complex with its specific protein inhibitor (25). Upon adjustment to $\mathrm{pH} 5.0$ a heavy precipitate formed in the supernatant and, without separation, the suspension was stirred for 21 hours at $30^{\circ} \mathrm{C}$. During this period carboxypeptidase activity appeared corresponding to $40-120 \mathrm{mg}$ enzyme per $1000 \mathrm{~g}$ of compressed yeast depending on the batch. The resulting, almost clear solution was centrifuged at $2900 \mathrm{rev} . / \mathrm{min}$ for $20 \mathrm{~min}$. It was observed that the specific activity of the carboxypeptidase was higher when the activation of the enzyme was carried out at $30^{\circ} \mathrm{C}$ as described above, instead of $25^{\circ} \mathrm{C}$ as described by LENNEY (22).

Before use, the affinity resin was regenerated with $0.01 \mathrm{M}-\mathrm{NaOH}$. It was packed in a $1.6 \times 5$ $\mathrm{cm}$ column and equilibrated with $0.01 \mathrm{M}$-MES buffer, pH 5.0. The activated autolysate was concentrated to approximately one quarter of its original volume by ultrafiltration in a high pressure cell with a DDS-600 membrane which 
retained all molecules with molecular weights above 20,000 . After adjustment to $\mathrm{pH} 5.0$, the concentrated autolysate was applied to the column. The affinity column was washed with approximately 2 liters of $1 \mathrm{M}-\mathrm{NaCl}$ containing $0.01 \mathrm{M}$-sodium acetate, $\mathrm{pH} 4.3$, to remove unspecifically bound protein. The washing was continued until the absorbance of the eluate at $280 \mathrm{~nm}$ was below 0.005 . Carboxypeptidase $\mathrm{Y}$ was eluted from the column with $0.1 \mathrm{M}$ solution of the competitive inhibitor succinic acid, adjusted to $\mathrm{pH} 5.0$ (Fig. 1). The eluate was concentrated by ultrafiltration and desalted on a 5 $\times 27 \mathrm{~cm}$ column of Sephadex G-25, fine grade, equilibrated with water. The enzyme in water solutions could be stored at $-18^{\circ} \mathrm{C}$ without loss of activity. However, lyophilization of such solutions resulted in approximately $50 \%$ loss of the enzymatic activity. In contrast, enzyme solutions in $0.1 \mathrm{M}$-sodium citrate, pH 5.3, could be lyophilized with no disadvantageous effects on the enzyme.

In an alternative procedure, the enzyme was eluted from the affinity column with $0.01 \mathrm{M}$ sodium phosphate buffer at $\mathrm{pH} 7.0$, which was outside of the $\mathrm{pH}$ range of strong binding between the carboxypeptidase $Y$ and the benzyl-

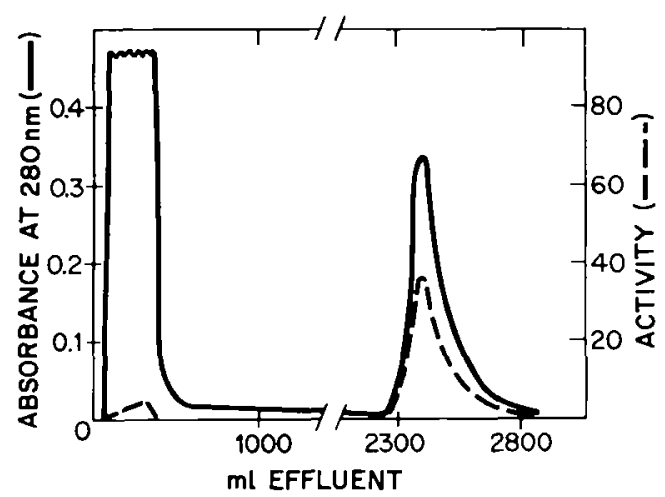

Figure 1. Purification of carboxypeptidase $Y$ by affinity chromatography on an a Sepharose-Gly-Tyrazo-benzylsuccinic acid gel. The column $(2.5 \times 9.3$ $\mathrm{cm}$ ) was equilibrated with $0.01 \mathrm{M}-\mathrm{MES}, \mathrm{pH} 5.0$. Concentrated extract $(190 \mathrm{ml})$ containing approximately $45 \mathrm{mg}$ of enzyme was applied on the column. The flow rate was $70 \mathrm{ml} / \mathrm{h}$. The column was washed extensively with 2 liters of $1 \mathrm{M}$-sodium chloride -0.01 $\mathrm{M}$-sodium acetate, $\mathrm{pH}$ 4.3. Elution was performed with $0.1 \mathrm{M}$-succinic acid, $\mathrm{pH} 5.0$. Activity is expressed in abitrary units. succinic acid ligand of the affinity column (Figure 2). The eluate was concentrated and desalted as described above. As seen from the examples listed in Table 1 , the two procedures gave approximately the same yield of enzyme, but the specific activity was slightly higher when the phosphate buffer was used for the elution.

\subsection{Physical chemical characterization of carboxypeptidase $Y$}

The carboxypeptidase $Y$ prepared according to both of the procedures described in Section 3.1 appeared homogeneous by electrophoresis on polyacrylamide gels at the $\mathrm{pH}$ values 4.3 and 8.8. As a further test of homogeneity, a preparation eluted with succinate was applied to a column of DEAE-Sephadex A-50 and eluted by a salt gradient as described by HAYASHI et al. (17). The enzyme was eluted as a single symmetrical peak. The specific activity was constant across the peak, and it was within one

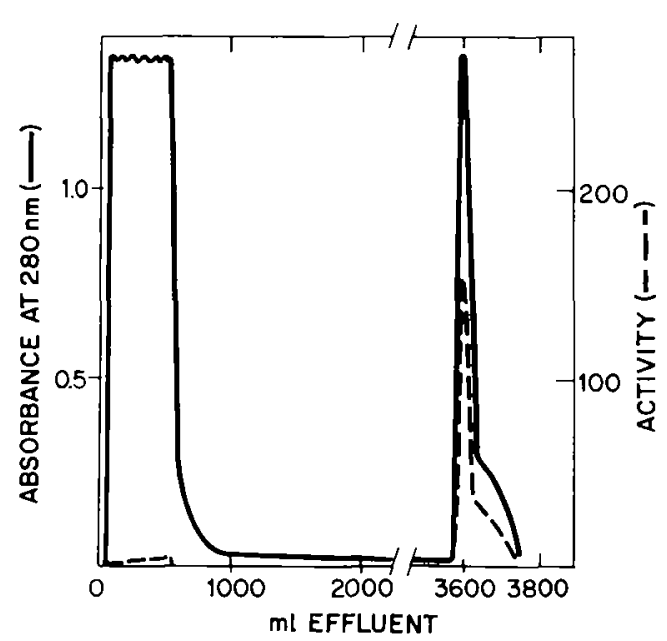

Figure 2. Purification of carboxypeptidase $\mathrm{Y}$ by affinity chromatography on a Sepharose-Gly-Tyrazo-benzylsuccinic acid gel. The column $(5 \times 2.3 \mathrm{~cm})$ was equilibrated with $0.01 \mathrm{M}-\mathrm{MES}$, pH 5.0. Concentrated extract $(320 \mathrm{ml})$ containing approximately $35 \mathrm{mg}$ of enzyme was applied on the column. The flow rate was $200 \mathrm{ml} / \mathrm{h}$. The column was extensively washed with 3 liters of $1 \mathrm{M}$-sodium chloride $-0.01 \mathrm{M}$ sodium acetate, $\mathrm{pH} 4.3$. The elution was performed with $0.01 \mathrm{M}$-phosphate buffer $\mathrm{pH}$ 7.0. Specific peptidase activity ( $\mu$ moles/min/mg protein) using Cbz-phe-Ala as substrate was performed as described in section 2 . 
per cent identical with the specific activity of the material applied to the column. A single symmetrical peak was also seen when carboxypeptidase $\mathrm{Y}$ was sedimented in the ultracentrifuge (Fig. 3). Sedimentations performed at the enzyme concentrations $9.3,7.0$ and 4.7 $\mathrm{mg} / \mathrm{ml}$ were extrapolated to give $\mathrm{S}^{0}{ }_{20 . \mathrm{w}}=4.41 \pm$ $0.02 \mathrm{~S}$. Within the concentration range tested, the sedimentation coefficient was independent of the enzyme concentration, and the value was consistent with the value found by AIBARA et al. (1).

The molecular weight was determined by sedimentation equilibrium according to the YPHANTIS method (33). The plot of the logarithm of the fringe displacement versus the square of the radial distance was linear (Figure 4) as expected for a homogeneous protein. The partial specific volume of carboxypeptidase $Y$ in $0.01 \mathrm{M}$-phosphate buffer, $\mathrm{pH} 7.0$, was determined by density measurements to be 0.720 at $20^{\circ} \mathrm{C}$. This value agreed reasonably well with the approximate value 0.71 estimated from the amino acid and carbohydrate composition (25). Using the more precise of these values, 0.720 , in combination with the data of the sedimentation equilibrium experiment the molecular weight was calculated to 64,600 Dalton. This is slightly above the value 61,000 Dalton found by AIBARA et al. (1), but part of this difference is explained from their use of the value 0.71 for the partial specific volume against our value of 0.72 .

SDS gel electrophoresis of carboxypeptidase $Y$ in the presence of mercaptoethanol exhibited a single band with a mobility corresponding to a molecular weight of approximately 60,000 Dalton (Fig. 5). The agreement between the molecular weights of the native and the unfolded enzyme confirms that it consists of a single polypeptide chain.

Isoelectric focusing of the enzyme preparation in an Ampholine gradient from $\mathrm{pH} 2.5$ to 4.0 revealed two overlapping peaks, corresponding to the isoelectric points of $\mathrm{pH} 3.56$ and 3.66 respectively (Fig. 6). Both components were enzymatically active, although the more acidic component appeared to have slightly less specific activity than the other component. Unfortunately, attempts to separate them by varying the conditions of elution from the affinity column were not successfull. AIBARA et al. (1) reported an isoelectric point of $\mathrm{pH} 3.60$ corresponding to the mean of our values, using

Table I

Affinity purification of carboxypeptidase $Y$.

Example 1.

\begin{tabular}{l|c|c|c|c}
\hline & $\begin{array}{c}\text { Volume } \\
\mathrm{ml}\end{array}$ & $\begin{array}{c}\text { Protein } \\
\mathrm{g}\end{array}$ & $\begin{array}{c}\text { Specific } \\
\text { activity }\end{array}$ & $\begin{array}{c}\text { Yield } \\
\%\end{array}$ \\
\hline $\begin{array}{l}\text { Activated extract pH 5.0 } \\
\text { After ultrafiltration }\end{array}$ & 1080 & 22.8 & 0.48 & $(100)$ \\
Eluate from affinity column & 190 & 10.9 & 1.00 & 99 \\
with 0.1 M-succinate pH 5 & 550 & 0.041 & 156 & 85 \\
\hline
\end{tabular}

Example 2.

\begin{tabular}{l|c|c|c|c}
\hline & $\begin{array}{c}\text { Volume } \\
\mathrm{ml}\end{array}$ & $\begin{array}{c}\text { Protein } \\
\mathbf{8}\end{array}$ & $\begin{array}{c}\text { Specific } \\
\text { activity }\end{array}$ & $\begin{array}{c}\text { Yield } \\
\%\end{array}$ \\
\hline $\begin{array}{l}\text { Activated extract pH 5.0 } \\
\text { After ultrafiltration }\end{array}$ & 1080 & 22.4 & 0.39 & $\begin{array}{c}(100) \\
99\end{array}$ \\
$\begin{array}{l}\text { Eluate from affinity column } \\
\text { with 0.01 M-phosphate pH 7 }\end{array}$ & 320 & 12.3 & 0.72 & 83 \\
\hline
\end{tabular}

In both Example 1 and Example 2 the starting material was $500 \mathrm{~g}$ compressed bakers' yeast. Protein concentrations are in the first steps approximate values obtained from optical densities using the factor $E_{280}^{0.1 \%} \mathrm{~nm}=1.48$ valid for the purified enzyme. Activities were expressed as micromoles Cbz-Phe-Ala hydrolyzed per minute per milligram at $25^{\circ} \mathrm{C}$ and at a substrate concentration of $2 \mathrm{mM}$ (Section 3.2). 

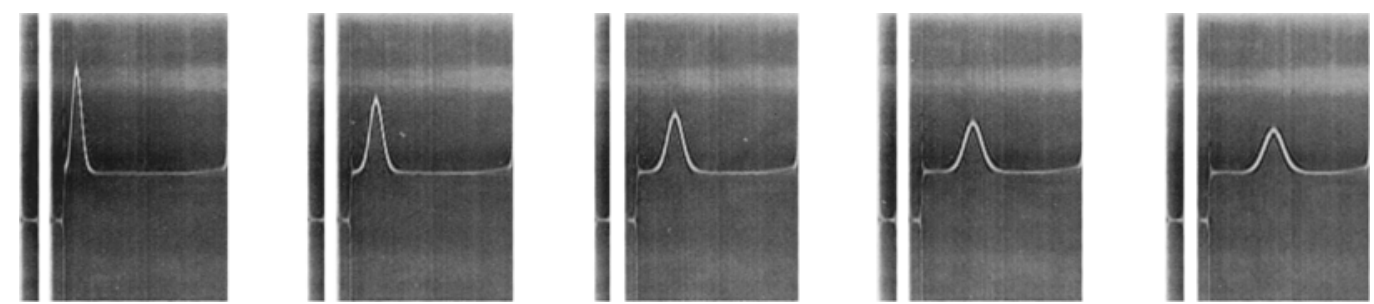

Figure 3. Sedimentation pattern of carboxypeptidase $Y$ at $59.780 \mathrm{rev} / \mathrm{min}$ using an enzyme concentration of $7.0 \mathrm{mg} / \mathrm{ml}$. The photographs were taken at the following times (minutes): $0,16,32,48$ and 64 .

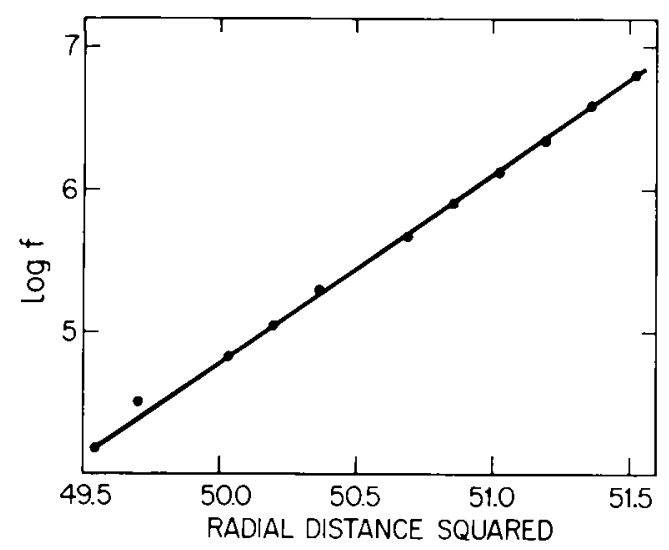

Figure 4. Sedimentation equilibrium of carboxypeptidase $Y$ performed at $17.980 \mathrm{rev} / \mathrm{min} A$ molecular weight of 64,600 was calculated from the slope of logarithm of the fringe displacement versus the radial distance sqared.

a steeper Ampholine gradient. The amino acid composition of carboxypeptidase $\mathrm{Y}$ is shown in Table Il. The enzyme was rich in carbohydrate with a glucosamine content corresponding to 9 10 residues and a total content of hexoses around $22 \%$ or approximately 88 residues. The amino acid composition of our enzyme preparation closely resembled the composition of the carboxypeptidase $\mathrm{Y}$ isolated by HAYASHI et al. (17) with only small differences in the values for alanine, methionine and half-cystine. Somewhat larger differences were observed when the present results were compared with those reported by KUHN et al. (21), and definite variations are seen between all three preparations with respect to carbohydrate contents.

\subsection{Enzymatic properties}

Incubation of yeast carboxypeptidase with the B-chain of oxidized insulin and native ribonuclease in $6 \mathrm{M}$-urea as described by HAYASHI et al. (17) released sequentially only the amino acids expected from the known C-terminal sequences of these proteins. The absence of extraneous amino acids confirmed that the isolated carboxypeptidase was free of endopeptidase activity.

The $\mathrm{pH}$-dependencies of the esterase activity towards ATEE and the peptidase activity towards Cbz-Phe-Ala (Figure 7) revealed narrow $\mathrm{pH}$ profiles with optima at $\mathrm{pH} 8.0$ and 6.75 , respectively. These values are in accordance with the pH-optima for peptide and ester substrates previously reported by HAYASHI et al. (15) and KuHN et al. (21).

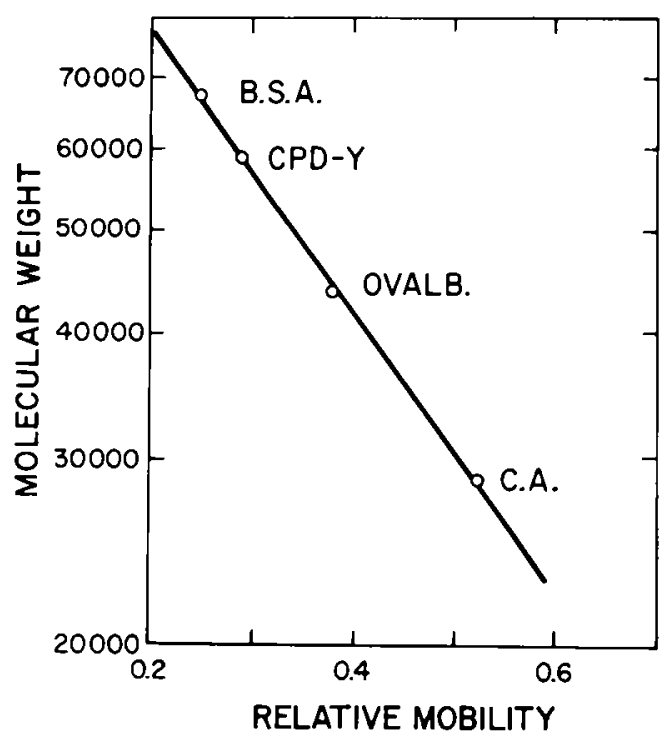

Figure 5. SDS-disc-gel-elctrophoresis of carboxypeptidase $Y$ using the following three markers: bovine serum albumin, ovalbumin and carbonic anhydrase. The mobility of carboxypeptidase $Y$, corresponded to a molecular weight around 60,000 . 


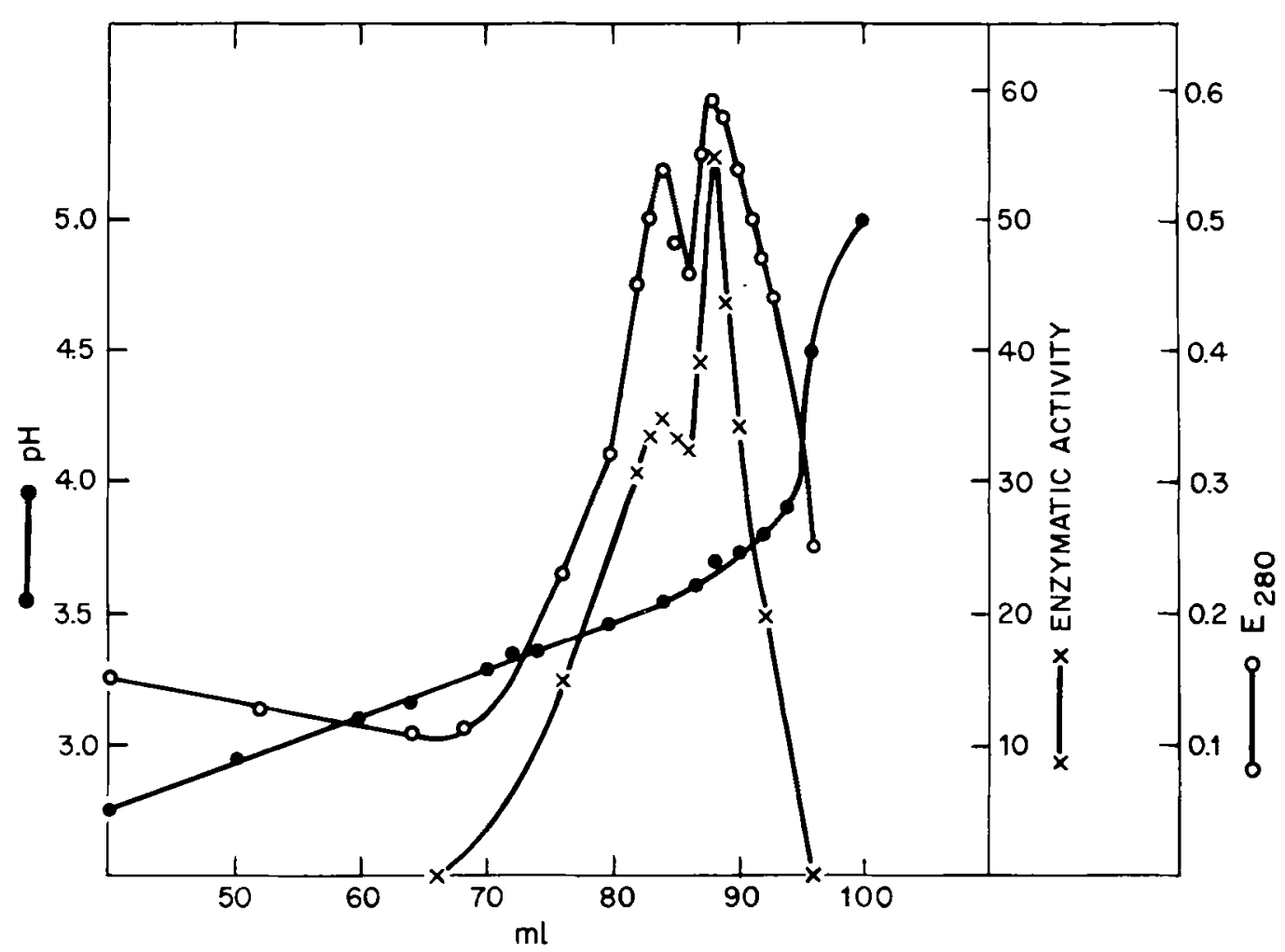

The kinetic parameters characterizing the reaction of carboxypeptidase $Y$ with various types of substrates are listed in Table III. The kinetics of the hydrolysis of Cbz-Phe-Ala was complicated and indicated $\mathrm{pH}$-dependent substrate inhibition. At pH 6.75 Lineweaver-Burk plots were linear only below a substrate concentration of $3.6 \mathrm{mM}$, and from this portion of the curve apparent $\mathrm{K}_{\mathrm{m}}$ and $\mathrm{k}_{\text {cat }}$ values of $0.6 \mathrm{mM}$ and $180 \mathrm{sec}^{-1}$, respectively, could be estimated. While the $K_{m}$ agrees with the value found by HAYASHI et al. (15) the value for $k_{\text {cat }}$ is approximately $50 \%$ higher than their value. Similarly, using Cbz-Phe-Leu as substrate, LineweaverBurk plots at $\mathrm{pH} 6.5$ were linear only at substrate concentrations below $3.6 \mathrm{mM}$, with apparent $K_{m}$ and $k_{\text {cat }}$ values of $0.2 \mathrm{mM}$ and $184 \mathrm{sec}^{-1}$, respectively. The substrate inhibition with this substrate was also noted by KUHN et al. (21). Our values for both $K_{m}$ and $k_{\text {cat }}$ are in this case significantly higher than the values reported by HAYASHI et al. (15) and BAI et al. (3). In contrast to peptide hydrolysis, no kinetic abnormalities were observed for the hydrolysis of ATEE, where the Lineweaver-Burk plots were linear
Figure 6. Isoelectric focusing of carboxypeptidase $Y$ in a pH-gradient from $\mathrm{pH} 2.5$ to $\mathrm{pH} 4$ (•). For operational details see section 2.7. The peptidase activity $(x)$ using Cbz-Phe-Ala as substrate is expressed as the change in absorbance per min at 230 $\mathrm{nm}$ obtained by adding a $10 \mu \mathrm{l}$ aliquot of each fraction to $1.0 \mathrm{ml}$ of substrate.

over the substrate concentration range employed. Between pH 6 and 8 the $K_{m}$ for hydrolysis of ATEE was constant while $k_{\text {cat }}$ varied with pH. HAYASHI et al. (15) also observed that the $K_{m}$ for the splitting of acetylphenylalanine ethyl ester was independent of $\mathrm{pH}$ within this range. However, with ATEE they again found lower $K_{m}$ values than we did. The enzymatic hydrolysis of HPLA exhibited linear Lineweaver-Burk plots with the kinetic parameters shown in Figure $8 . k_{\text {cal }}$ revealed a maximum at about $\mathrm{pH} 7.75$, while $\mathrm{K}_{\mathrm{m}}$ increased rapidly with increasing $\mathrm{pH}$. In contrast to the previous substrates, our data with HPLA indicated a considerably lower $\mathbf{K}_{\mathbf{m}}$ value in comparison with HAYASHI's data at $\mathrm{pH}$ $6(15)$.

Typical inhibitors of carboxypeptidase A such as benzylsuccinic acid and $\beta$-phenylpropionic 
Table II.

Amino acid composition of carboxypeptidase $Y$

\begin{tabular}{|c|c|c|c|}
\hline Amino acid & $\begin{array}{c}\text { Experimental } \\
\text { values. } \\
\text { Residues per } \\
64600\end{array}$ & $\begin{array}{c}\text { Hayashi et al. } \\
\text { (3) } \\
\text { Residues per } \\
61000\end{array}$ & $\begin{array}{l}\text { Kuhn et al. } \\
(21) \text {. } \\
\text { Residues per } \\
62000\end{array}$ \\
\hline Aspartic acid & 65.1 & 64.7 & 68.5 \\
\hline Threonine & $18.3^{a)}$ & 18.0 & 19.5 \\
\hline Serine & $29.7^{\mathbf{a})}$ & 30.0 & 31.1 \\
\hline Glutamic acid & 40.4 & 41.1 & 45.3 \\
\hline Proline & 24.7 & 24.9 & 25.8 \\
\hline Glycine & 34.2 & 33.6 & 36.2 \\
\hline Alanine & 22.3 & 24.8 & 24.0 \\
\hline Valine & $28.5^{b)}$ & 29.7 & 31.6 \\
\hline Methionine & $5.0 c)$ & 7.2 & 6.6 \\
\hline Isoleucine & $19.8^{b)}$ & 19.8 & 19.7 \\
\hline Leucine & 35.6 & 36.8 & 35.0 \\
\hline Tyrosine & 24.9 & 23.7 & 23.2 \\
\hline Phenylalanine & $25.2^{\text {b) }}$ & 26.7 & 23.5 \\
\hline Histidine & 8.9 & 9.2 & 8.0 \\
\hline Lysine & 17.7 & 18.6 & 16.7 \\
\hline Arginine & 9.4 & 8.7 & 8.8 \\
\hline Half-cystine & $8.9 \mathrm{~d})$ & 11.3 & 12.6 \\
\hline Tryptophan & $10.5 e)$ & 10.6 & 12.1 \\
\hline Glucosamine & 9.5 a) & 15.9 & 9.0 \\
\hline Hexose & 88 & 57 & 48 \\
\hline
\end{tabular}

The experimental values were based on the average of two amino acid analyses after hydrolysis in hydrochloric acid for 24,48 or 72 hours. The content of glucosamine was based on analyses after 3,6 and 8 hours of hydrolysis. The content of hexose was determined by the phenol sulphuric acid method.
a) extrapolated to zero time.
b) value after 72 hours of hydrolysis.
c) determined as methionine sulfone after performic acid oxidation.
d) determined as cysteic acid after performic acid oxidation.
e) determined spectrophotometrically by the method of Goodwin and Morton (14).

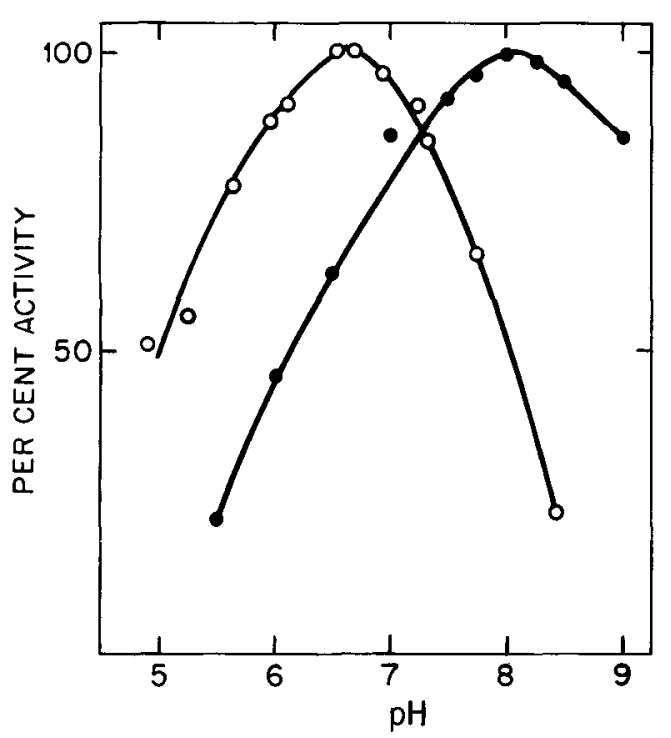

acid were inhibitors of carboxypeptidase $Y$ (Table IV). Succinic acid was only a weak inhibitor and acetate did not have any influence on the activity.

The activity of the carboxypeptidase $Y$ was totally destroyed by treatment with DFP, confirming the involvement of a serine residue in the catalytic mechanism of the enzyme. The additional observation was made that transition state analogs for the serine proteases also inhibited carboxypeptidase $\mathrm{Y}$. The $\mathrm{pH}$-dependence of the inhibition with benzeneboronic

Figure 7. pH-dependence of peptidase activity against $\mathrm{Cbz}$-Phe-Ala $(O)$ and esterase activity against ATEE (๑) expressed as per cent of the maximum rate of hydrolysis. 
Table III.

Kinetic parameters of carboxypeptidase $Y$

\begin{tabular}{|c|c|c|c|c|c|c|}
\hline \multirow[t]{2}{*}{ Substrate } & \multirow[t]{2}{*}{$\mathrm{pH}$} & \multicolumn{2}{|c|}{ Experimental values } & \multicolumn{2}{|c|}{ Literature values } & \multirow[b]{2}{*}{ Reference } \\
\hline & & $\mathbf{k}_{\text {cat }}$ & $\mathrm{K}_{\mathrm{m}}$ & $\mathbf{k}_{\text {cat }}$ & $\mathrm{K}_{\mathrm{m}}$ & \\
\hline Cbz-Phe-Ala & 6.75 & $\begin{array}{c}\left(\mathrm{sec}^{-1}\right) \\
180\end{array}$ & $\begin{array}{c}(\mathrm{mM}) \\
0.6\end{array}$ & $\begin{array}{c}\left(\mathrm{sec}^{-1}\right) \\
120\end{array}$ & $\begin{array}{c}(\mathrm{mM}) \\
0.56\end{array}$ & (15) \\
\hline Cbz-Phe-Leu & 6.5 & 184 & 0.2 & $\begin{array}{l}130 \\
143\end{array}$ & 0.10 & $(15)$ \\
\hline ATEE & $\begin{array}{l}6.0 \\
7.0 \\
8.0\end{array}$ & $\begin{array}{l}116 \\
136 \\
169\end{array}$ & $\begin{array}{l}7.2 \\
7.2 \\
7.2\end{array}$ & $\begin{array}{l}113 \\
105\end{array}$ & $\begin{array}{l}4.2 \\
2.4\end{array}$ & $\begin{array}{c}(3) \\
\text { (15) }\end{array}$ \\
\hline HPLA & 6.0 & 18 & 0.06 & 21 & 0.45 & (15) \\
\hline
\end{tabular}

acid, p-aminophenylarsonic acid and p-aminophenylphosphonic acid is shown in Figure 9. In all cases the inhibition was instantaneous. Since $\mathbf{K}_{\mathrm{m}}$ for the hydrolysis of ATEE was constant in the $\mathrm{pH}$ interval 6 to 8 , the variation of the inhibition of the enzyme by these competitive inhibitors reflected variations of $\mathrm{K}_{\mathrm{j}}$ with $\mathrm{pH}$.

The enzyme was inhibited by the sulfhydryl group reagents $\mathrm{PHMB}$ and $\mathrm{HgCl}_{2}$ (Figure 10) indicating the involvement of an - $\mathrm{SH}$ group in the enzymatic activity. The inhibition by PHMB was complete when Cbz-Phe-Ala and ATEE were used as substrates, but incomplete with HPLA as substrate. This difference is hardly due to experimental errors since BAI and HAYASHI (2) recently have described a related observation of total inactivation by PHMB with Cbz-Phe-Leu as substrate, but no inactivation at all when HPLA was used as substrate. In contrast to $\mathrm{PHMB}, \mathrm{HgCl}_{2}$ completely and stoichiometrically inhibited both the activities towards Cbz-Phe-Ala and HPLA.

\section{DISCUSSION}

The affinity chromatographic procedures described for the purification of carboxypeptidase $Y$ in the present work are less tedious than the methods described by HaYASHI et al. (17) and KUnN et al. (21). Furthermore, the yield is larger, approximately 85 per cent, and the method is easily adapted for large scale preparations both as column and as batch procedures, although with a slightly smaller yield. It was found to be important to always saturate the affinity gel with carboxypeptidase $Y$ before the elution was started in order to keep the elution volume small and the specific activity high.

The isolated enzyme was homogeneous by disc-

Table IV.

Inhibition of purified carboxypeptidase $Y$

\begin{tabular}{l|c|c|c}
\hline Inhibitor & Conc & \multicolumn{2}{|c}{ \% Peptidase activity } \\
& $(\mathrm{mM})$ & $\mathrm{pH}=5.0$ & $\mathrm{pH}=6.75$ \\
\hline D, L-benzylsuccinic acid & 0.1 & 81 & 97 \\
& 1.0 & 34 & 87 \\
B-phenylpropionic acid & 1.0 & 74 & 80 \\
Succinic acid & 10 & 22 & 56 \\
& 10 & 100 & 100 \\
Sodium acetate & 100 & 58 & 94 \\
\hline
\end{tabular}




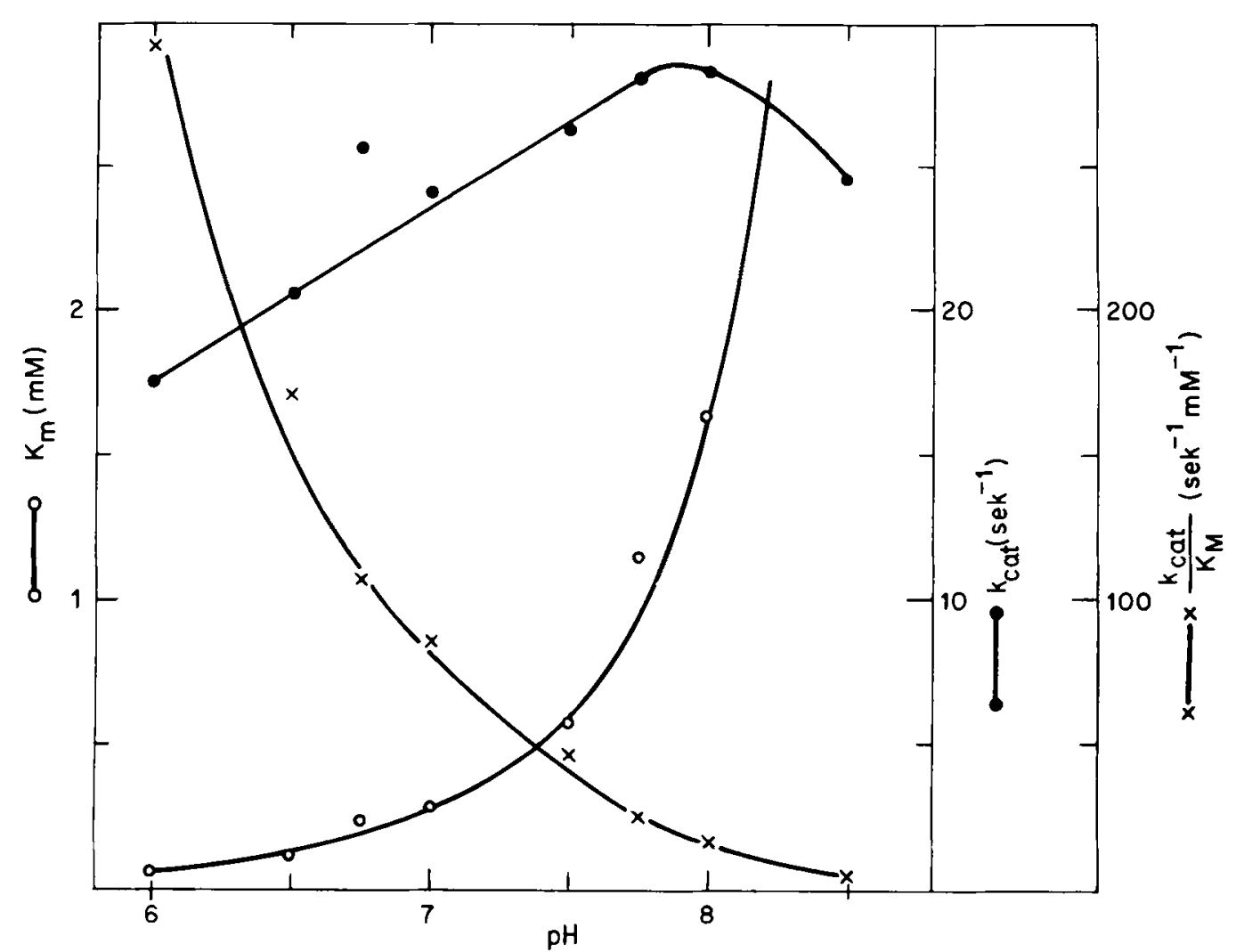

Figure 8. $\mathrm{pH}$-dependence of the kinetic parameters, $\mathrm{k}_{\mathrm{cat}}(\bullet), \mathrm{K}_{\mathrm{m}}(\mathrm{O})$ and $\mathrm{k}_{\mathrm{cat}} / \mathrm{K}_{\mathrm{m}}(\mathrm{x})$, for the enzymatic hydrolysis of HPLA. All the calculations were based on Lineweaver-Burk plots at the $\mathrm{pH}$-values indicated.

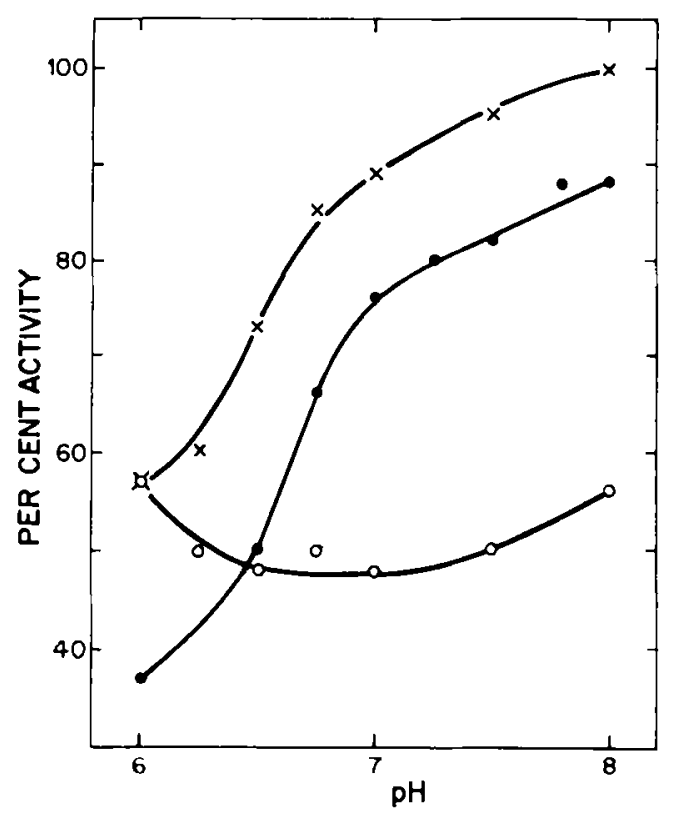

gel-electrophoresis and ultracentrifugation analysis, but isoelectric focusing demonstrated two enzymatically active peaks, corresponding to isoelectric points of $\mathrm{pH} 3.56$ and 3.66 , respectively. The existence of more than one form of carboxypeptidase $Y$ was also indicated from the slight differences in chemical composition between the enzyme isolated by us and the corresponding enzyme, isolated from Fleischman type of baker's yeast. The even more pronounced differences in the kinetic constants between the present preparation and the enzymes used by Hayashi and coworkers

Figure 9. pH-dependence of the inhibition of carboxypeptidase $Y$ by $1 \mathrm{mM}$ p-aminophenylphosphonic acid $(x), 1 \mathrm{mM}$-aminophenylarsonic acid $(\bullet)$ and 1 $\mathrm{mM}$ benzeneboronic acid $(O)$. The degree of inhibition was determined by assaying the esterase activity toward ATEE in the absence and in the presence of the inhibitor. No preincubation time was necessary, the inhibition was instantaneous. The inhibition by $p$ aminophenylarsonic acid and p-aminophenylphosphonic acid is dependent on the protonation of a group with a pK of 6.6 . 


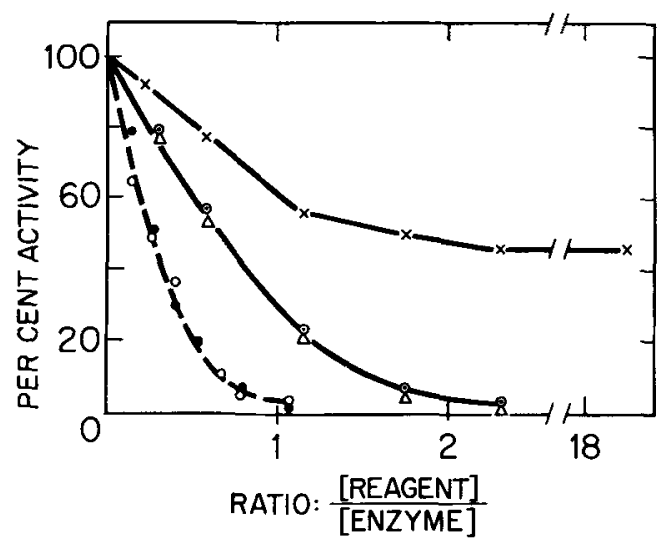

Figure 10. Inhibition of carboxypeptidase $\mathrm{Y}$ by $\mathrm{HgCl}_{2}$ $(--)$ and PHMB (-_). The enzymatic activity was assayed after incubation for 1 hour with the reagent. Activities against $\mathrm{Cbz}$-Phe-Ala $(\odot, \bigcirc)$, activity against $\operatorname{ATEE}(\Delta)$, and activities against $\operatorname{HPLA}(\bullet, \mathbf{x})$. The inhibition is expressed as the per cent of the activity in a similar experiment without the inhibitor.

point in the same direction. One possible explanation of the origin of the multiple forms of carboxypeptidase $\mathrm{Y}$ might be due to the fact that the carboxypeptidase $\mathrm{Y}$ has to be isolated after an autolysis step at $\mathrm{pH} 5.0$ to remove its specific protein inhibitor (25). During this autolysis the enzyme might undergo a limited proteolysis resulting in the multiple forms. Another explanation might be that its specific inhibitor has been insufficiently degraded during the autolysis, with the result that some fragments bind to the enzyme. Further experiments are required to distinguish between these possibilities.

The active site properties of carboxypeptidase $\mathrm{Y}$ appear to be quite different from those of the pancreatic carboxypeptidases, since it has no essential metal but, in contrast, has a serine hydroxyl at the active center (4) similar to the typical serine endopeptidases, e.g. the chymotrypsin and the subtilisin family of proteases. Furthermore, carboxypeptidase $Y$ also hydrolyses typical chymotrypsin ester substrates, i.e. acetyltyrosine ethyl ester, whereas the pancreatic carboxypeptidases only hydrolyse ester substrates with a free carboxyl group. Chloromethyl ketone reagents modified one histidine residue in carboxypeptidase $\mathrm{Y}$ con- comitantly with an irreversible inactivation of the enzyme (16), suggesting the presence of an essential histidyl residue at the active center participating in a charge-relay system, similar to chymotrypsin. The close relationship between carboxypeptidase $\mathrm{Y}$ and the serine proteinases is further underlined by the inhibition by p-aminophenylarsonic acid, p-aminophenylphosphonic acid, and phenylboronic acid, three transition state analogs for the serine proteinases (5). Apparently, the inhibition by both $\mathrm{p}$-aminophenylarsonic acid and $\mathrm{p}$ aminophenylphosphonic acid is dependent on the protonation of a group with a pK of 6.6 (Fig. 9). If this group were situated on the inhibitor, the $\mathrm{pH}$ dependence of the inhibition by the arsonic acid and phosphonic acid would have exhibited different $\mathrm{pH}$-dependencies, since the $\mathrm{pK}_{2}$ for these two acids are 8.9 and 7.5, respectively $(19,29)$. Hence, the simplest interpretation of the results is that binding of these two inhibitors requires a positive charge at the active site. The identity of this group is not clear. However, based on similar studies on chymotrypsin and subtilisin GLAzER (13) has suggested that the monovalent anion of the inhibitor binds to the protonated histidine in the charge-relay system, and this suggestion is in accordance with recent crystallographic studies (5). Whether the binding of these inhibitors to carboxypeptidase-Y can be similarly correlated to a group controlling the enzymatic activity is currently under investigation.

X-ray crystallographic studies of boronic acid adducts with subtilisin Novo have confirmed the transition state analog nature of these inhibitors (26). The inhibition of subtilisin Novo by benzeneboronic acid is dependent on two groups on the enzyme with pK's of 7.0 and 8.9 (24). Only little $\mathrm{pH}$-dependence was seen for the inhibition of carboxypeptidase $\mathrm{Y}$ in the investigated $\mathrm{pH}$-range (Fig. 9), indicating that the group controlling the enzymatic activity of this serine-enzyme is quite different from that of the typical serine proteases. Thus, even though carboxypeptidase-Y seems to exhibit many properties at its active site and in its mechanism similar to serine proteases, substantial differences also exist. 


\section{ACKNOWLEDGEMENTS}

We thank Professor M. SokolovsKY and Dr. L. PETERSON for suggesting the use of benzylsuccinate as ligand for affinity chromatography purification of Carboxypeptidase-Y. We also thank Dr. Aa. HvidT for the loan of the Anton Paar, model DMA 02 densitometer. $\mathrm{K}$. BREDDAM thanks the United Breweries, Ltd. for a student fellowship.

\section{REFERENCES}

1. Aibara, S., Hayashi, R. and Hata, T.: Physical and chemical properties of yeast proteinase $C$. Agr. Biol. Chem. 35: 658-66 (1971)

2. BAI, Y. and HAYASHI, R.: A possible role for a single cysteine residue in carboxypeptidase $Y$. FEBS Letters 56: 43-45 (1975)

3. BAI, Y., HAYASHI, R. and HATA, T.: Kinetic studies of carboxypeptidase Y. J. Biochem. (Tokyo): 78: 617-626 (1975)

4. Bang-Jensen, V., Foltmann, B. and Rombauts, W.: Studies on rennin. $X$ : On the proteolytic specificity of rennin. Compt. Rend. Trav. Lab. Carlsberg 34: 326-345 (1964)

5. Birktoft, J., Matthews, D. M., Poulus, T. A. and KRAUT, J.: A crystallographic view of the serine protease mechanism. Fifth LinderstrømLang Conference, Vingsted, Denmark (1975)

6. Brewer, J. M. and Ashworth, R. B.: Disc electrophoresis. J. Chem. Ed. 46: 41-45 (1969)

7. Byers, L. and Wolfenden, R.: Binding of the byproduct analog benzylsuccinic acid by carboxypeptidase A. Biochemistry 12: 2070-2077 (1973)

8. Cohn, E. J. and Edsall, J. T.: Proteins, amino acids and peptides, p. 370 , Reinhold, New York (1943)

9. Cuntracasas, P.: Protein purification by affinity chromatography. Derivatization of agarose and polyacrylamide beads. J. Biol. Chem. 245: 30593065 (1970)

10. DAvis, B. J.: Disc electrophoresis, method and application to human serum proteins. Ann. N. Y. Acad. Sci. 121: 404-427 (1964)

11. Dol, E., Hayashi, R. and Hata, T.: Purification of yeast proteinases. Agr. Biol. Chem. 31: 160-169 (1967)

12. Dubois, M., Gilles, K. A., Hamilton, J. K., Rebers, P. A. and SMITH, F.: Colorimetric method for determination of sugar and related substances. Anal. Chem. 38: 350-356 (1956)

13. GlazER, A. N.: Inhibition of serine* esterases by phenylarsonic acids. J. Biol. Chem. 243: 36933701 (1968)

14. Goodwin, T. W. and Morton, R. A.: The spectrophotometric determination of tyrosine and tryptophan in proteins. Biochem. J. 40: 628632 (1946)
15. Hayashi, R., Bal, Y. and Hata, T.: Kinetic studies of carboxypeptidase Y. J. Biochem. (Tokyo) 77: 69-79 (1975)

16. HAYASHI, R., BAI, Y. and HATA, T.: Evidence for an essential histidine in carboxypeptidase $\mathrm{Y}$. J. Biol. Chem. 250: 5221-5226 (1975)

17. Hayashi, R., Moore, S. and Stein, W. H.: Carboxypeptidase from yeast. J. Biol. Chem. 248: 2296-2302 (1973)

18. HiRs, C. H. W.: Determination of cystine as cysteic acid. Methods Enzymol. 11: 59-62 (1967)

19. JaFFe, H. H., Freedman, L. D. and Doak, C. O.: The acid dissociation constants of aromatic phosphonic acids. I. Meta and Para substituted compounds. J. Am. Chem. Soc. 75: 2209-2211 (1953)

20. Kratky, O., Leopold, H. and Stabinger, H.: The determination of the partial specific volume of proteins by the mechanical oscillator technique. Methods Enzymol. 27: 98-1 10 (1972)

21. Kuhn, R. W., WAlsh, K. A. and Neurath, H.: Isolation and partial characterization of an acid carboxypeptidase from yeast. Biochemistry 13: 3871-3877 (1974)

22. LENNEY, J. F.: A study of two yeast proteinases. J. Biol. Chem. 221: 919-930(1956)

23. Liao, T. H., Salnikow, J., Moore, S., and Stein, W. H.: Bovine pancreatic deoxyribonuclease A. J. Biol. Chem. 248: 1489-1495 (1973)

24. Lindeuist, R. N. and Terry, C.: Inhibition of subtilisin by boronic acid, potential analogs of tetrahedral reaction intermediate. Arch. Biochem. Biophys. 160: 135-144 (1974)

25. Matern, H., Hoffman, M. and Holzer, H.: Isolation and characterization of the carboxypeptidase $Y$ inhibitor from yeast. Proc. Nat. Acad. Sci. U. S. A. 71:4874-4878 (1974)

26. Matthews, D. A., Alden, R. A., Birktoft, J. J., Freer, S. T., and Kraut, J.: X-ray crystallographic study of boronic acid adducts with subtilisin BPN' (Novo): A model for the catalytic transition state. J. Biol. Chem. 250: 7120 (1975)

27. Moore, S. and Stein, W. H.: Chromatographic determination of amino acids by the use of automatic recording equipment. Methods Enzymol. 6: 819-831 (1963)

28. OTtesen, M. and Spector, A.: A comparison of two proteinases from Bacillus subtilis. Compt. Rend. Trav. Lab. Carisberg 32: 63-74 (1960)

29. Pressman, D. and Brown, D. H.: Ionization constants of several substituted phenylarsonic acids. J. Am. Chem. Soc. 65: 540-543 (1943)

30. Sorensen, S. P. L. and Hoyrup, M.: On the preparation of egg-albumin solutions of well-defined composition, and on the analytical methods used. Compt. Rend. Trav. Lab. Carlsberg 12: 1267 (1917)

31. Thiers, R. E.: Contamination in trace element analysis and its control. Methods. Biochem. Anal. 5: 273-336 (1957) 
32. Weber, K., Pringle, J. R. and Osborn, M.: Measurement of molecular weights by electrophoresis on SDS-acrylamide gel. Methods Enzymol. 26: 3-27 (1972)

33. Y PHANTIS, D. A.: Equilibrium ultracentrifugation of dilute solutions. Biochemistry 3: 297-317 (1964)
34. Zuber, H. and Martile, P. H.: Acid carboxypeptidases: their occurence in plants, intracellular distribution and possible function: $Z$. Naturforsch. 23b: 663-665 (1968) 